\title{
Actinomyces meyerii
}

National Cancer Institute

\section{Source}

National Cancer Institute. Actinomyces meyerii. NCI Thesaurus. Code C86109.

A species of anaerobic, Gram positive, rod shaped bacteria assigned to the phylum Actinobacteria. This bacteria is catalase negative, not beta hemolytic and does not hydrolyze esculin. A. meyerii is a causative agent of actinomycosis. 